\title{
Population structure of albacore Thunnus alalunga inferred from blood groups and tag-recapture analyses
}

\author{
Haritz Arrizabalaga ${ }^{1, *}$, Eduardo Costas $^{2}$, Javier Juste ${ }^{3}$, Alberto González-Garcés ${ }^{4}$ \\ Blanca Nieto ${ }^{2}$, Victoria López-Rodas ${ }^{2}$ \\ ${ }^{1}$ AZTI Fundazioa, Herrera Kaia Portualdea z/g, 20110 Pasaia (Gipuzkoa), Spain \\ ${ }^{2}$ Genética, Facultad de Veterinaria, Universidad Complutense, Avenida Puerta de Hierro s/n, 28080 Madrid, Spain \\ ${ }^{3}$ CSIC, Estación biológica Doñana, Avenida $M^{\text {a }}$ Luisa s/n, 41013 Sevilla, Spain \\ ${ }^{4}$ IEO, Cabo Estay, Canido, Apdo 1552, Vigo (Pontevedra), Spain
}

\begin{abstract}
Samples of albacore Thunnus alalunga from 6 locations worldwide were used for blood group analysis according to the binding patterns of 8 different lectins. Conventional tag recapture data was reviewed and a spatially structured tag attrition model was fitted to data from the North Atlantic and the Mediterranean. Blood group analyses suggest that: (1) the Pacific population is the most distant from the others, (2) the Indian and the South Atlantic populations are proximate, (3) the North Atlantic and the Gulf of Guinea populations are proximate, (4) the Gulf of Guinea and the North Atlantic are distant from South Atlantic, and (5) the Mediterranean and the North Atlantic populations are distant. Migration rates between the North Atlantic and the Mediterranean obtained from the tag attrition model were low and thus, consistent with genetic results.
\end{abstract}

KEY WORDS: Thunnus alalunga · Population structure · Blood group · Lectin · Tag recapture · Migration rate

\section{INTRODUCTION}

A stock is a population unit assumed to be homogeneous for particular management purposes (Begg \& Waldman 1999). When managing a fishery to obtain a given sustainable yield, assumed stock structure must be based on knowledge about real population structure of an exploited species (Carvalho \& Hauser 1994). Otherwise, overfishing of less productive stocks or underexploitation of more productive ones can occur (Begg et al. 1999). Avoiding overfishing and the risk of collapse is of great importance, since populations' potential for rapid recovery after prolonged declines does not seem to be as general as previously thought (Hutchings 2000).

In spite of this, knowing the population structure of widely spread and highly migratory species like tunas may be problematic. In the case of albacore Thunnus alalunga, Bonn. 1788, a temperate tuna species distributed between latitudes $45^{\circ} \mathrm{N}$ and $45^{\circ} \mathrm{S}$ throughout the Pacific, Indian and Atlantic Oceans, it is assumed that the northern and southern Atlantic stocks are separated by the $5^{\circ} \mathrm{N}$ parallel (ICCAT 2001), although there may be some small interchange of individuals between them (Beardsley 1969, Koto 1969, GonzálezGarcés 1997). The albacore caught as bycatch by tropical purse seiners around the Atlantic equator may be an indicator of such a possibility. The northern stock is considered to be independent of the Mediterranean stock based on the existence of a separate spawning area in the Mediterranean (Lalami et al. 1973, Dicenta et al. 1975), different morphometrics (Bard 1981), different growth rates and age at first maturity (Arena et al. 1980), and tagging data and larvae distri- 
bution (FAO 1994). In spite of this, some AtlanticMediterranean interchange of individuals has been recorded through tagging experiments (Arrizabalaga et al. 2002), and Viñas et al. (1999) and Pujolar et al. (2003) found no genetic differentiation among samples from several locations on the NE Atlantic and the western Mediterranean.

Although Indian Ocean albacore is considered as a single stock within the Indian Ocean Tuna Commission (IOTC), different studies on larvae concentration zones (Stequert \& Marsac 1989), morphometric (Penney et al. 1998) and genetic characteristics (Yeh et al. 1996) of Indian Ocean albacore suggest that there are 2 albacore populations in this ocean delimited by the $90^{\circ} \mathrm{E}$ meridian. In the Pacific Ocean, a hemispheric stock structure for albacore is accepted. Although biological parameters and fishery statistics support a 2 stock hypothesis in the North Pacific (Laurs \& Lynn 1991), length frequency, spawning ground and tag recapture analyses (Nakano 1996) as well as genetic studies (Chow \& Ushiama 1995) indicate that there are no differences among the North Pacific albacore. Based on tagging information, it is assumed that there is a single stock of albacore in the South Pacific Ocean (SPC 2002).

Uncertainties in population structure can be addressed using various methods, including genetic ones. Lectins have been used widely as cell markers (Slifkin \& Doyle 1990). Lectins are proteins or glycoproteins of non-immune origin that agglutinate cells and/or precipitate complex carbohydrates (reviewed by Liener et al. 1986, Slifkin \& Doyle 1990). Due to the fact that many different membrane proteoglycans and glycolipids are present, the cell surface can be precisely characterized using fluorescein isothiocyanate (FITC) labelled lectins that are detectable under fluorescent light (Slifkin \& Doyle 1990). Lectins are isolated from a wide variety of natural sources including seeds, plants, fungi, bacteria, seaweed, sponges, corals, molluscs, fishes, invertebrates and mammals. Several lectins behave like blood group antibodies and agglutinate various blood groups of erythrocytes (Nance 1986). These lectins (called phytohemagglutinins) can be used as specific gene markers. For example, the lectin from Dolichus biflorus reacts specifically with A1 erythrocytes from animals with the A1 allele (Issit 1985, Nance 1986).

Recently, new procedures that allow the preparation of an unlimited number of novel lectins with diverse specificities have been developed using genetic engineering (Yim et al. 2001). Frequencies of blood groups in natural populations have constituted a useful tool to analyse genetic structure of natural populations, differentiate races and interpret migration rates (CavalliSforza 1963, Edwards \& Cavalli-Sforza 1964, Cavalli-
Sforza \& Bodmer 1981, Nicholas 1987), but their use in aquatic organisms has been very limited and usually restricted to an immunological approach. In this work, we characterize frequencies of blood groups of Thunnus alalunga populations using lectins.

Tagging is a valuable tool to address stock structure issues, both to assess the migratory pattern of a species in a qualitative manner and to compute migration rates between specific areas in a quantitative way. In any case, a good experimental design is required, with a large number of fish tagged simultaneously in the different geographic areas. Spatially structured tag attrition models (Hilborn 1990, Schwarz et al. 1993, Anganuzzi et al. 1994) have been applied to compute migration rates of intensively tagged tuna species such as Thunnus maccoyii (Hampton 1991), Thunnus albacares and Thunnus obesus (Sibert et al. 2000).

In general, the use of different techniques leads to a better perception of the population structure and various authors suggest such a holistic approach (Pawson \& Jennings 1996, Begg \& Waldman 1999, Waldman 1999). In that sense, the aim of this paper was to analyse the population structure of Thunnus alalunga by means of 2 parallel procedures, (1) blood group analysis using lectins and (2) classic tag recapture procedures. Concordance among these procedures and others by other authors was studied to assess the usefulness of lectins as markers of Thunnus alalunga fish populations.

\section{MATERIALS AND METHODS}

Blood group analyses. 139 albacore from the western Mediterranean, NE Atlantic, Gulf of Guinea, South Atlantic, central Indian, SW Indian and SE Pacific were sampled by scientific observers aboard Spanish fishing vessels (Table 1). Individuals in each area were collected on different days and positions in order to sample different schools and reduce sampling error, as suggested by Viñas et al. (1999). Using heparynized vaccutainers $5 \mathrm{ml}$ of blood was obtained from the branchia artery from each of the 139 albacore. Blood samples were conserved at $4^{\circ} \mathrm{C}$ until study in laboratory. Erythrocyte integrity and bacterial amount was checked for all individuals and only blood in excellent condition was used. From each fish, 3 aliquots of $50 \mu \mathrm{l}$ blood were washed in isotonic phosphate buffered salline (PBS) and treated with 8 FITC labelled lectins (Table 2) for $1 \mathrm{~h}$ at $20^{\circ} \mathrm{C}$ in accordance with the manufacturer's recommendations as in Costas \& LópezRodas (1994). After the incubation period, the erythrocytes were washed 3 times in PBS and observed under a Zeiss axiovert microscope with an FITC filter set for epifluorescence to detect positive or negative lectin 
Table 1. Thunnus alalunga. Sample description

\begin{tabular}{|lcccl|}
\hline Area & Latitude & Longitude & $\mathrm{n}$ & \multicolumn{1}{c|}{ Date } \\
\hline Western Mediterranean & $36^{\circ} \mathrm{N}$ & $1-2^{\circ} \mathrm{W}$ & 41 & November 1999 \\
Northeast Atlantic & $45^{\circ} \mathrm{N}$ & $3-5^{\circ} \mathrm{W}$ & 20 & August 1996 \\
Gulf of Guinea & $1^{\circ} \mathrm{N}$ & $15-16^{\circ} \mathrm{W}$ & 23 & $\begin{array}{l}\text { November 1999- } \\
\text { January 2000 }\end{array}$ \\
South Atlantic & $19-24^{\circ} \mathrm{S}$ & $10-24^{\circ} \mathrm{W}$ & 28 & $\begin{array}{l}\text { November 1999- } \\
\text { February 2000 } \\
\text { Southwest Indian }\end{array}$ \\
Central Indian & $27-29^{\circ} \mathrm{S}$ & $38-58^{\circ} \mathrm{E}$ & 10 & May 1998 \\
Southeast Pacific & $2-4^{\circ} \mathrm{S}$ & $66-72^{\circ} \mathrm{E}$ & 10 & January 1998 \\
& $37^{\circ} \mathrm{S}$ & $80-81^{\circ} \mathrm{W}$ & 7 & April-May 2000 \\
\hline
\end{tabular}

during the period 1988-1991 to fit a spatially structured tag-attrition model and calculate movement rates between the North Atlantic and Mediterranean stocks. As there is no evidence of migrations of tagged albacore between other areas in which there is genetic sampling, only these 2 areas are considered for computing movement rates from conventional tagging data.

Eight tag release groups were identified and recoveries (from GonzálezGarcés \& Arrizabalaga 2002) were stratified in subsequent (up to 6) years at liberty (Table 3). We fitted the model

binding. All tests were read 'blind' (the person reading the test did not know the identity of the sample) and at least 2 different persons observed each sample.

The heterogeneity and geographic differentiation among populations was tested by a $\chi^{2}$ test as well as a $G$-test based on likelihood-ratio (Sokal \& Rohlf 1995). Euclidean distances were estimated (Cavalli-Sforza \& Bodmer 1981) and a cluster analysis was performed employing the complete linkage procedure (Hartigan 1975). Samples from the central and SW Indian Ocean were considered as being from the same Indian population because sampling was not enough to consider 2 different subpopulations.

Tag recapture analyses. A total of 23780 albacore have been tagged in the North Pacific (Bertignac et al. 1999), over 20000 in the South Pacific, 26274 in the Atlantic and Mediterranean; there is no knowledge of any albacore tagged in the Indian Ocean. A detailed review of the number of albacore tagged by year and area for the period 1960 to 2001 in the Atlantic and Mediterranean, reconstructed from the International Commission for the Conservation of Atlantic Tunas (ICCAT), Instituto Español de Oceanografía (IEO), Cooperative Tagging Center (CTC, Dr. Ortiz, pers. comm.), and Institut Français de Recherche pour l'Exploitation de la Mer (IFREMER, Dr. Liorzou, pers. comm.) databases showed that only 273 albacore were tagged in the South Atlantic, and the number of tags in the North Atlantic (21496) is an order of magnitude higher than in the Mediterranean (4505). The period 1988 to 1991 is the only one during which tagging cruises were carried out simultaneously in the northern Atlantic and the Mediterranean, with the number of tags released yearly being approximately of the same order of magnitude.

For this reason, we selected conventional tagging information from cruises proposed by Xiao (1996), but incorporating tag reporting and immediate tag shedding rates. Another variation was that our recapture data stratification in time did not require releases to be done at the beginning of each period, so that the model was rewritten as:

$$
\begin{gathered}
N_{i, a, t+1}^{\prime}=\sum_{j=1}^{n} N_{i, j, t}^{\prime}\left(1-q_{j} E_{j, t}\right) e^{\left(-M-w_{2}\right)} p_{j, a}+T_{i, a, t}\left(1-W_{1}\right) \\
R_{i, a, t}^{\prime}=N_{i, a, t}^{\prime} q_{a} E_{a, t} \beta_{a}
\end{gathered}
$$

$R_{i, a, t}^{\prime}$ is the expected number of recoveries from release group $i$, in area a (A: Atlantic or M: Mediterranean) at year $t_{i} T_{i, a, t}$ is the number of tags released in release group $i$, area a at year $t_{i} w_{1}$ is the proportion of tag losses due to Type I tag shedding; $w_{2}$ is the proportion of tag losses due to Type II tag shedding; $\beta_{a}$ is the tag reporting rate in area $a\left(\beta_{\mathrm{A}}\right.$ or $\left.\beta_{\mathrm{M}}\right) ; q_{a}$ is the catchability coefficient in a given area; $E_{a, t}$ is the fishing effort in area $a$ at year $t_{i}$ $M$ is the instantaneous natural mortality rate; $N_{i, a, t}^{\prime}$ is the expected number of tagged fish from release group $i$ present in area $a$ at year $t_{i} p_{j, a}$ is the proportion of fish moving each year from spatial strata $j$ to $a$.

The fishing effort in the North Atlantic was standardized as in Sibert et al. (2000) and reflected the trend for the mean fishing mortality of ages 1 to $8+$ in the area for the period 1988 to 1994 (ICCAT 2001). The fishing effort in the Mediterranean is not known, so the stan-

\begin{tabular}{|c|c|c|c|}
\hline Lectin & Abbreviation & $\begin{array}{l}\text { Specificity } \\
\text { on sugars }\end{array}$ & Blood group \\
\hline Phytolacca americana & PWM & $(\text { glcNAc })_{3}$ & \\
\hline Concanavaline A & Con A & $\alpha$-man, $\alpha$-glc & \\
\hline Glycine maxima & SBA & galNAc & \\
\hline Triticum vulgare & WGA & $(\text { glcNAc })_{2}$, NeuNAc & \\
\hline Erythrina cristagalli & ECA & $\beta$-gal $(1->4) \operatorname{glcNAc}$ & \\
\hline Vicia villosa & VVA & galNAc & $\mathrm{At}+\mathrm{Tn}$ \\
\hline Pisum sativum & PEA & $\alpha$-man & \\
\hline Tetraglonolobus purpureas & TPA & $\alpha$-l-fuc & $\mathrm{H}$ \\
\hline
\end{tabular}

Table 2. Lectins used in this study and their binding specificities 
Table 3. Thunnus alalunga. Tag release and recapture information used to fit the tag attrition model. Numbers in the 'Recapture' columns indicate the number of fish of a given tag group recaptured in the same area of release at subsequent years at liberty. The number of recoveries in the opposite spatial strata is given in brackets. $T_{i, a, t}$ number of tags released in release group $i$, area $a$ at year $t_{i}$ A: North Atlantic; M: Mediterranean

\begin{tabular}{|c|c|c|c|c|c|c|c|c|c|c|}
\hline \multirow{3}{*}{$\begin{array}{l}\text { Tag } \\
\text { group }\end{array}$} & \multicolumn{2}{|c|}{ Release } & \multirow{3}{*}{$T_{i, a, t}$} & \multirow{2}{*}{\multicolumn{7}{|c|}{$\begin{array}{l}\text { Recapture- } \\
\text { Years at liberty }\end{array}$}} \\
\hline & Area & Year & & & & & & & & \\
\hline & & & & 0 & 1 & 2 & 3 & 4 & 5 & 6 \\
\hline 1 & A & 1988 & 536 & $30(0)$ & $7(0)$ & $0(0)$ & $1(0)$ & $0(0)$ & $0(0)$ & $0(0)$ \\
\hline 2 & M & 1988 & 239 & $0(0)$ & $0(0)$ & $2(0)$ & $0(0)$ & $0(0)$ & $0(0)$ & $0(0)$ \\
\hline 3 & $\mathrm{~A}$ & 1989 & 3085 & & $54(0)$ & $32(0)$ & $8(0)$ & $5(0)$ & $0(0)$ & $0(0)$ \\
\hline 4 & M & 1989 & 1392 & & $3(0)$ & $7(0)$ & $3(0)$ & $0(0)$ & $0(1)$ & $0(0)$ \\
\hline 5 & $\mathrm{~A}$ & 1990 & 4642 & & & $36(0)$ & $38(0)$ & 11 (1) & $1(0)$ & $0(0)$ \\
\hline 6 & M & 1990 & 580 & & & $2(0)$ & $4(0)$ & $0(0)$ & $1(0)$ & $0(0)$ \\
\hline 7 & $\mathrm{~A}$ & 1991 & 4396 & & & & $106(0)$ & $45(0)$ & $9(0)$ & $4(0)$ \\
\hline 8 & M & 1991 & 1592 & & & & $3(0)$ & $0(0)$ & $0(0)$ & $1(1)$ \\
\hline
\end{tabular}

dardized fishing effort was assumed to be equal to 1. Catchabilities were assumed to be constant over time and, as a first step, equal in both areas. Natural mortality rate was assumed to be equal to 0.3 , as in ICCAT (2001). It was assumed that no migration to the South Atlantic occurs, so that for a given tag release group:

$$
\sum_{i, j} p_{i, j}=1
$$

Reporting rate was assumed to be 0.8 in both areas, following Ortiz de Zárate \& Bertignac (2002). Tag shedding rates computed by Laurs et al. (1976) for the North Pacific albacore were used. Only proportions of fish moving yearly from the Atlantic to the Mediterranean $\left(p_{\mathrm{AM}}\right)$ and from the Mediterranean to the Atlantic $\left(p_{\mathrm{MA}}\right)$ as well as the catchability in the Atlantic $\left(q_{\mathrm{A}}\right)$ were estimated in the model.

Parameter estimation was done by maximizing the Poisson maximum likelihood function (Xiao 1996) with the quasi-Newton method (Press et al. 1992); $95 \%$ confidence intervals of the estimates were calculated with
400 parametric bootstrap iterations assuming that observed recoveries followed a Poisson distribution with mean $R_{i, a, t}^{\prime}$ (Xiao 1996). Model fit was assessed according to the deviance values in each point and for the whole model (Lebreton et al. 1992), and correlation between estimated parameters was checked by doing pairwise plots of the bootstrap parameter estimates (Anganuzzi et al. 1994).

We tested the sensitivity to assumptions of equal catchability and reporting rates in both areas, by allowing the catchability in the Mediterranean $\left(q_{\mathrm{M}}\right)$ be 0.4 to 1.4 times $q_{\mathrm{A}}$, and allowing each reporting rate to vary independently in the range of 0.1 to 1 .

\section{RESULTS}

\section{Blood group analyses}

Lectins seem to be useful tools for rapid and precise characterization of surface moieties in albacore ery-

Table 4. Thunnus alalunga. Lectin binding pattern (blood groups) obtained in different populations. +: number of positive binding fishes; -: number of negative binding fishes. Differentiation among populations was tested by a $\chi^{2}$ test and a $G$-test. Abbreviations as in Table 2

\begin{tabular}{|c|c|c|c|c|c|c|c|c|c|c|c|c|c|c|c|c|}
\hline & \multicolumn{2}{|c|}{ PWM } & \multicolumn{2}{|c|}{ Con A } & \multicolumn{2}{|c|}{ SBA } & \multicolumn{2}{|c|}{ WGA } & \multicolumn{2}{|c|}{ ECA } & \multicolumn{2}{|c|}{ VVA } & \multicolumn{2}{|c|}{ PEA } & \multicolumn{2}{|c|}{ TPA } \\
\hline & + & - & + & - & + & - & & - & & - & + & - & & - & + & - \\
\hline Mediterranean & 0 & 41 & 0 & 41 & 1 & 40 & 23 & 18 & 0 & 41 & 1 & 40 & 0 & 41 & 0 & 41 \\
\hline North Atlantic & 0 & 20 & 5 & 15 & 2 & 18 & 9 & 11 & 1 & 19 & 1 & 19 & 0 & 20 & 0 & 20 \\
\hline Gulf of Guinea & 0 & 23 & 5 & 18 & 1 & 22 & 9 & 14 & 1 & 22 & 0 & 23 & 0 & 23 & 0 & 23 \\
\hline Souh Atlantic & 1 & 27 & 1 & 27 & 6 & 22 & 8 & 20 & 0 & 28 & 0 & 28 & 0 & 28 & 0 & 28 \\
\hline Indian Ocean & 0 & 20 & 0 & 20 & 6 & 14 & 8 & 12 & 0 & 20 & 0 & 20 & 0 & 20 & 0 & 20 \\
\hline Pacific Ocean & 4 & 3 & 0 & 7 & 2 & 5 & 5 & 2 & 0 & 7 & 0 & 7 & 0 & 7 & 0 & 7 \\
\hline$\chi^{2}(p)$ & \multicolumn{2}{|c|}{$\begin{array}{c}61.76 \\
(0.0000)\end{array}$} & \multicolumn{2}{|c|}{$\begin{array}{c}20.61 \\
(0.0010)\end{array}$} & \multicolumn{2}{|c|}{$\begin{array}{c}14.14 \\
(0.0147)\end{array}$} & \multicolumn{2}{|c|}{$\begin{array}{c}7.60 \\
(0.1797)\end{array}$} & \multicolumn{2}{|c|}{$\begin{array}{c}4.56 \\
(0.4719)\end{array}$} & \multicolumn{2}{|c|}{$\begin{array}{c}3.22 \\
(0.6661)\end{array}$} & & & & \\
\hline$G(\mathrm{p})$ & \multicolumn{2}{|c|}{$\begin{array}{c}24.88 \\
(0.0001)\end{array}$} & \multicolumn{2}{|c|}{$\begin{array}{c}21.70 \\
(0.0006)\end{array}$} & \multicolumn{2}{|c|}{$\begin{array}{c}14.61 \\
(0.0122)\end{array}$} & \multicolumn{2}{|c|}{$\begin{array}{c}7.73 \\
(0.1718)\end{array}$} & \multicolumn{2}{|c|}{$\begin{array}{c}4.77 \\
(0.4446)\end{array}$} & \multicolumn{2}{|c|}{$\begin{array}{c}3.59 \\
(0.6098)\end{array}$} & & & & \\
\hline
\end{tabular}


throcytes. The optical examination of the quality of lectin binding demonstrated that all the erythrocytes of a fish show a similar lectin binding pattern. They presented bright stain, or they were not bound at all, but mixed patterns of stained and unstained erythrocytes were not observed. Concordance between different readers was reached in all cases, suggesting that interobserver bias is negligible when trying to detect positive and negative binding (this may not be the case in experiments where the purpose is also to quantify the degree of fluorescence, e.g. in Costas \& López-Rodas 1994). The lectin-binding pattern (blood groups) of a great number of fishes can be easily analyzed. Consequently, the frequency of lectin binding patterns can be analyzed from a population point of view, to detect variability within populations and geographic differentiation among populations.

There is substantial genetic variability within all populations of Thunnus alalunga analyzed (Table 4). Most of the lectins (PWM, Con A, SBA, WGA, ECA, VVA) were able to detect variability within populations. Only 2 lectins (TPA, which detects the human blood $\mathrm{H}$, and PEA) were useless in $T$. alalunga. In addition, we detected highly significant heterogeneity and considerable geographic differentiation among T. alalunga populations. Some lectins (PWM, Con A and SBA) are useful tools to detect significant differences among populations of $T$. alalunga.

A cluster analysis representing the Euclidean distances (ED) among the analyzed populations (Fig. 1) showed that: (1) the Pacific population is the most distant from the others, (2) Indian and South Atlantic populations are proximate (ED =0.1515), (3) Gulf of Guinea and North Atlantic populations are proximate $(\mathrm{ED}=0.1012)$, (4) Gulf of Guinea and South Atlantic populations are distant (ED =0.2766), (5) North and South Atlantic populations are also distant $(\mathrm{ED}=$ 0.3037), and (6) the Mediterranean population is distant from the North Atlantic population (ED = 0.2893).

\section{Tag recapture analyses}

The tag recovery rate from fish tagged in the Atlantic was much higher than that in the Mediterranean (3.06 and $0.74 \%$ respectively); $95 \%$ confidence intervals of parameter estimates from the tag attrition model for $p_{\mathrm{AM}}, p_{\mathrm{MA}}$ and $q_{\mathrm{A}}$ were $(0-0.0149),(0.0179-0.0904)$ and (0.0128-0.0154), respectively, showing that $p_{\mathrm{AM}}$ is not significantly different from 0 and $p_{\mathrm{MA}}$ is also low. The estimated parameters were not correlated with one another, total deviance of the model was 402 and fitting diagnostics showed that the model adjusted the trends in observed recaptures for each tag group in each spatial strata quite well. Highest individual point

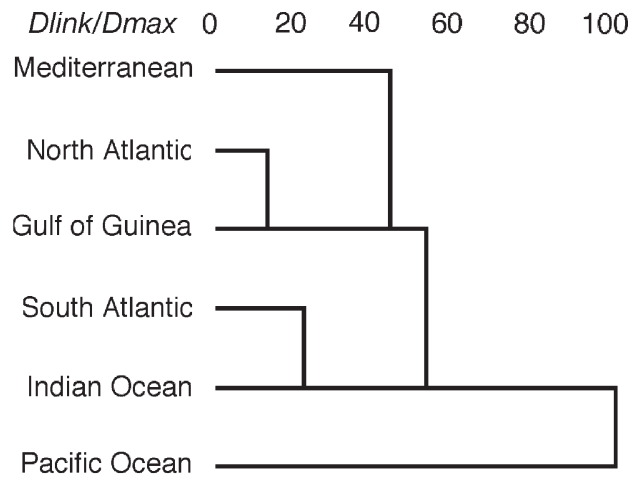

Fig. 1. Thunnus alalunga. Blood group based cluster analysis (Euclidian distances of a complete linkage procedure) summarising distances among populations. Dlink/Dmax: distance between 2 populations with respect to the maximum distance observed

deviance values were observed for the first year at liberty of tag group 7 and 1 in the North Atlantic, and tag groups 8 and 4 in the Mediterranean (81.46, 68.29, 19.76 and 12.42 , respectively). For the first year, the model predicted fewer than observed recoveries for groups tagged in the North Atlantic (Groups 1, 3 and 7 ), and more than observed recoveries for the groups tagged in the Mediterranean. This suggested different trials to estimate both $q_{\mathrm{A}}$ and $q_{\mathrm{M}}$, and also to estimate $q_{\mathrm{A}}$ while forcing $q_{\mathrm{M}}$ to be 0.1 to 0.5 times $q_{\mathrm{A}}$. This way, total deviance values were lower but some points still had deviance values of the same order of magnitude as in the initial fit and $p_{\mathrm{AM}}$ values were unreliable (around $0.40)$, so the initial fit was accepted as the best option.

The average $p_{\mathrm{MA}}$ values are quite stable around the assumed reporting rate values of 0.8 , but tend to decrease when reporting rate in the Mediterranean is lower than in the Atlantic (Fig. 2). Average $p_{M A}$ values also tend to decrease if the catchability in the Mediterranean is considered lower than in the Atlantic (Fig. 3).

\section{DISCUSSION}

Recent studies sequencing the control region III (Viñas et al. 1999) and analyzing allozymes (Pujolar et al. 2003) have failed to find differentiation among the Mediterranean and Atlantic populations of albacore, concluding that other markers should be used in population characterization. In our study, the distance between Mediterranean and North Atlantic albacore populations based on blood group results was very high. In fact, the lectin binding patterns obtained in both populations differed substantially, especially with the lectin Concanavaline A that showed highest differences in observed frequencies (Fisher's exact test; $\mathrm{p}=0.0026$ ). 


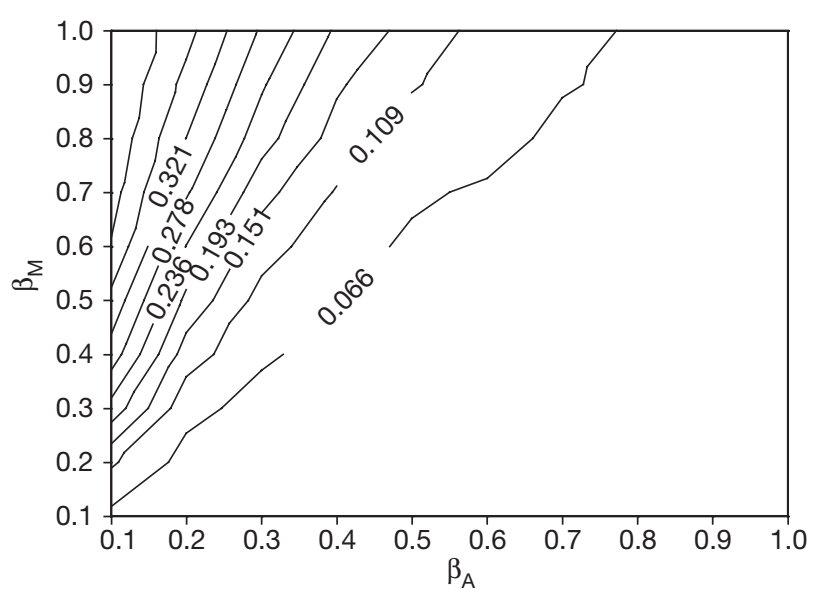

Fig. 2. Thunnus alalunga. Average annual migration rates from the Mediterranean to the Atlantic $\left(p_{\mathrm{MA}}\right)$ for varying area specific reporting rates $\left(\beta_{\mathrm{A}}\right.$ and $\beta_{\mathrm{M}}$ ). Mean values of the 400 bootstrap iterations for each combination of reporting rates are shown

Tag release experiments carried out on albacore worldwide have not been designed to compute migration rates between areas. In spite of this, the time period selected allowed estimates of migration rates between the North Atlantic and the Mediterranean populations. If catchability or tag reporting rate in the Mediterranean were lower than in the Atlantic, mean $p_{\text {MA }}$ would be lower than estimated. Having standardized the fishing effort, relative catchabilities reflect the relative magnitude of the fishing mortality in both areas. Although the fishing mortality in the Mediterranean is not known, it seems reasonable to think that this will be lower than in the Atlantic, where most com-

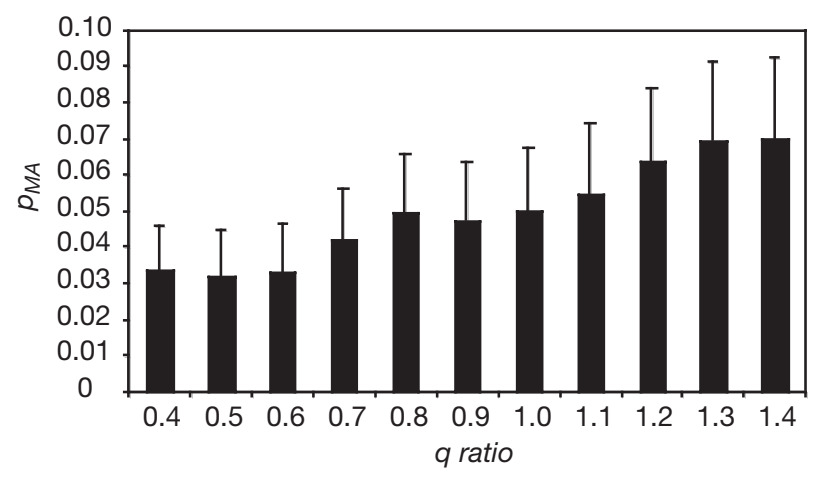

Fig. 3. Thunnus alalunga. Variation of annual migration rates from the Mediterranean to the Atlantic $\left(p_{\mathrm{MA}}\right)$ with assumed values of $q$ ratio $\left(q\right.$ ratio $=q_{\mathrm{M}} / q_{\mathrm{A}}$ ), with both reporting rates set equal to 0.8. Average values and standard deviations from 400 bootstrap iterations are shown mercial fisheries operate. On the other hand, according to De Metrio et al. (1997), the lower recovery rates observed in the Mediterranean are due to the lack of collaboration by fishermen in this area at the time of reporting recovered tags. The recovery rate observed in the Atlantic during the present study period was 4.13 times higher than in the Mediterranean. If this were exclusively due to differences in reporting rates, the estimated $p_{\mathrm{MA}}$ would be even lower than 0.0269 (estimated with $\beta_{\mathrm{A}}=0.8$ and $\beta_{\mathrm{M}}=0.2$ ). Moreover, the impact of this migration in the Atlantic gene pool would be negligible when considering the relative size of both populations (Mediterranean stock abundance estimates are not available but reported catches are only $4.84 \%$ the ones in the North Atlantic during the study period). It is also important to take into account that migration observed with tag recapture experiments does not necessarily mean successful reproduction in the new area and genetic mixing.

After all these considerations regarding the interpretation of tag recapture results, we consider that these are concordant with the blood group analyses, in the sense that they fully support the differentiation of the Mediterranean population, recognized in the literature and coincident with assumed stock structure in ICCAT for management purposes.

Blood group analyses also suggest a further differentiation between the Atlantic and the Pacific-Indian populations. This differentiation is supported by the highly significant heterogeneity found between the Atlantic and Pacific populations in a recent RFLP analysis on the mitochondrial ATPase gene (Chow \& Ushiama 1995), and a similar pattern is also found in cogeneric bigeye tuna (Chow et al. 2000) and other large pelagic fishes such as the swordfish (AlvaradoBremer et al. 1999). Blood group analyses are consistent with this differentiation.

A more detailed insight into blood group results shows a clear north-south differentiation in the Atlantic Ocean (supported by Takagi et al. 2001), the southern Atlantic population being closer to the Indian Ocean population. In this respect, Yeh et al. (1998) showed differences between mtDNA sequences from the South Atlantic and the eastern Indian Ocean. In spite of this, the same authors, based on homogeneity of catch rate statistics, suggest that some intermingling of immature fish between both oceans may occur during the southern hemisphere summer, as was also suggested by Koto (1969). Penney et al. (1998) also found morphometric differences between the Indian and the Atlantic albacore populations, the Agulhas current acting as a superficial frontier between them, but suggested that there may be some limited and sporadic interchange of adult albacore in deep waters. Our blood group results are in agreement with this hypo- 
thesis, although more loci should be tested to support this.

According to blood group analyses, the Pacific and Indian populations are distant. These analyses were performed by pooling samples from the central and SW Indian Ocean, because of the low sample size in each subpopulation. Nevertheless, preliminary analyses did show quite different lectin binding patterns between both subpopulations, so further studies with proper sampling designs should be conducted to confirm the Indian substructuring hypothesis suggested by several authors (Stequert \& Marsac 1989, Yeh et al. 1996, Penney et al. 1998).

We present the first blood group analyses conducted with albacore from the Gulf of Guinea, which is located close to the limit currently assumed for the North and South Atlantic stocks. Results showed that they are much closer to the northern population than to the southern one. This is not in accordance with the present stock structure assumed in ICCAT, according to which they belong to the southern stock, as they are south of $5^{\circ} \mathrm{N}$ (ICCAT 2001). Although the importance of this misclassification may be limited for management purposes, because catches in that area are not important, more studies should be conducted in order to determine their origin and ecological role in relation to the life cycle of Atlantic albacore.

Takagi et al. (2001) suggested that DNA microsatellites may be more adequate than mtDNA for future albacore population subdivision studies. We suggest that blood group analyses using lectin binding patterns may also be a tool with good potential for fish population identification when sampling of blood in good condition is possible, as it is more rapid and effortless than other procedures. Although factors affecting lectin binding specificities have not been detected in other species (e.g. Aguilera \& González-Gil 2001), potential factors affecting the variability of binding specificities in tunas should be further studied.

Our study supports the view that the stock structure assumed by international tuna management organizations has a genetic basis, and the lack of interstock migrations observed worldwide (other than between the Mediterranean and the North Atlantic) is concordant with it. Nevertheless, more intensive genetic sampling in space would allow checking whether assumed boundaries between stocks reflect real boundaries between populations. Properly designed tagging experiments would also allow better estimates of the interchange between them. Results from these studies should be properly taken into account at the time stocks are assessed in order to reduce uncertainty in the assessments related to assumed stock structure and optimize management strategies success in albacore.
Acknowledgements. We would like to thank S. Pérez, M. Puyol and D. Carrera for laboratory assistance, the tuna research teams from IEO and AZTI for their collaboration in sampling, Dr. M. Ortiz and Dr. B. Liorzou for the information on tagging campaigns, Prof M. Rico for critical reading of the manuscript, the Spanish Comisión de Ciencia y Tecnología (CICYT) and its CYTMAR program for co-funding the MAR98-0233 project, and an anonymous reviewer for useful comments on the manuscript.

\section{LITERATURE CITED}

Aguilera A, González-Gil S (2001) Lectin analysis of surface saccharides during the cell cycle in four dinoflagellate species. J Exp Mar Biol Ecol 256:149-166

Alvarado-Bremer JR, Mejuto J, Gómez-Márquez J, Viñas J and 6 others (1999) Hierarchical analysis of nucleotide diversity reveals extremely low levels of mitochondrial DNA gene flow between northeast Atlantic and Mediterranean swordfish populations. Collect Vol Sci Pap Int Com Conserv AH Tuna 49:467-475

Anganuzzi A, Hilborn R, Skalski JR (1994) Estimation of size selectivity and movement rates from mark-recovery data. Can J Fish Aquat Sci 51:734-742

Arena P, Potoschi A, Cefali A (1980) Risultati preliminari di studi sull'etá, l'accrescimento a la prima maturitá sessuale dell'alalunga Thunnus alalunga (Bonn., 1788) del Tirreno. Mem Biol Mar Oceanogr 10:71-81

Arrizabalaga H, López-Rodas V, Ortiz de Zárate V, Costas E, González-Garcés A (2002) Study on the migrations and stock structure of albacore (Thunnus alalunga) from the Atlantic Ocean and the Mediterranean Sea based on conventional tag release-recapture experiences. Collect Vol Sci Pap Int Com Conserv AH Tuna 54:1479-1494

Bard FX (1981) Le thon germon (Thunnus alalunga Bonnaterre 1788) de l'Ocean Atlantique. De la dynamique des populations à la strategie demographique. PhD thesis, Université de Paris

Beardsley GL (1969) Proposed migrations for albacore, Thunnus alalunga, in the Atlantic Ocean. Trans Am Fish Soc 98: 589-598

Begg GA, Waldman JR (1999) An holistic approach to fish stock identification. Fish Res 43:35-44

Begg GA, Friedland KD, Pearce JB (1999) Stock identification and its role in stock assessment and fisheries management: an overview. Fish Res 43:1-8

Bertignac M, Hampton J, Coan AL Jr (1999) Estimates of exploitation rates for north Pacific albacore, Thunnus alalunga, from tagging data. Fish Bull 97:421-433

Carvalho GR, Hauser L (1994) Molecular genetics and the stock concept in fisheries. Rev Fish Biol Fish 4:326-350

Cavalli-Sforza LL (1963) Genetic drift for blood groups. In: Goldschmidt E (ed) Genetics of migrants and isolated populations. Williams \& Wilkins, Baltimore

Cavalli-Sforza LL, Bodmer WF (1981) The genetics of human populations. Freeman, San Francisco

Chow S, Ushiama H (1995) Global population structure of albacore (Thunnus alalunga) inferred by RFLP analysis of the mitochondrial ATPase gene. Mar Biol 123:39-45

Chow S, Okamoto H, Miyabe N, Hiramatsu K, Barut N (2000) Genetic divergence between Atlantic and Indo-Pacific stocks of bigeye tuna (Thunnus obesus) and admixture around South Africa. Mol Ecol 9:221-227

Costas E, López-Rodas V (1994) Identification of marine dinoflagellates using fluorescent lectins. J Phycol 30: 987-990 
De Metrio G, Cacucci M, Sion L, Acone F, Sanna L, Palmieri G (1997) Results of tagging surveys on albacore (Thunnus alalunga, Bonn.) carried out in the northern Ionian and southern Adriatic Sea from 1990 to 1995. Biol Mar Mediterr 4:515-517

Dicenta A, Piccinetti C, Piccinetti-Manfrin G (1975) Observaciones sobre la reproducción de los túnidos en las Islas Baleares. Bol Inst Esp Oceanogr 204:27-37

Edwards AWF, Cavalli-Sforza LL (1964) Reconstruction of evolutionary trees. In: Heywood VE, McNeill J (eds) Phenetic and phylogenetic classification. The Systematics Association, London, p 67-76

FAO (1994) Expert consultation on stocks of large pelagic fishes in the Mediterranean area. Iraklion (Crete) Greece, 17-23 September 1992. FAO Fish Rep 494

González-Garcés A (1997) Contribución al conocimiento de la dinámica de la población del atún blanco (Thunnus alalunga, Bonn. 1788) del Atlántico Norte. PhD thesis, Universidad Complutense de Madrid

González-Garcés A, Arrizabalaga H (2002) Update of albacore tag release-recapture information in the North Atlantic and Mediterranean for the period 1968-1999. Collect Vol Sci Pap Int Com Conserv AH Tuna 54:1454-1478

Hampton J (1991) Estimation of southern bluefin tuna Thunnus maccoyii natural mortality and movement rates from tagging experiments. Fish Bull 89:591-610

Hartigan JA (1975) Clustering algorithms. Wiley, New York

Hilborn R (1990) Determination of fish movement patterns from tag recoveries using maximum likelihood estimators. Can J Fish Aquat Sci 47:635-643

Hutchings JA (2000) Collapse and recovery of marine fishes. Nature 406:882-885

ICCAT (2001) Report of the ICCAT SCRS albacore stock assessment session (Madrid, Spain, October 9 to 15, 2000). Collect Vol Sci Pap Int Com Conserv AH Tuna 52:1283-1390

Issit PD (1985) Applied blood group serology. Montgomery Scientific Publications, Miami

Koto T (1969) Studies on the albacore - XIV. Distribution and movement of the albacore in the Indian and the Atlantic Oceans based on the catch statistics of Japanese tuna longline fishery. Bull Far Seas Fish Res Lab 1:115-129

Lalami Y, Tallai S, Barrois JM, Piccinetti C, Piccinetti-Manfrin G (1973) Observations sur les oeufs et larves des thonidés des côtes algériennes. Pelagos Bull Inst Sci Mer Amenage Littoral 4:54-65

Laurs RM, Lynn RJ (1991) North Pacific albacore ecology and oceanography. In: Wetherall JA (ed) Biology, oceanography, and fisheries of the north Pacific transition zone and subarctic frontal zone. NOAA Tech Rep NMFS 105:69-88

Laurs RM, Lenarz WH, Nishimoto RN (1976) Estimates of rates of tag shedding by north Pacific albacore, Thunnus alalunga. Fish Bull 74:675-678

Lebreton JD, Burnham KP, Clobert J, Anderson DR (1992) Modeling survival and testing biological hypotheses using marked animals: a unified approach with case studies. Ecol Monogr 62:67-118

Liener IE, Sharon N, Goldstein IJ (eds) (1986) The lectins: properties, functions and applications in biology and medicine. Academic Press, London

Nakano H (1996) Review of biology and fisheries of albacore in the North Pacific Ocean. Collect Vol Sci Pap Int Com Conserv AH Tuna 43:269-272

Nance ST (1986) Serology of the ABH and Lewis blood group systems. In: Wallace ME, Gibbs FL (eds) Blood group systems: ABH and Lewis. Karger, Bethesda, MD, p 57-81
Nicholas FW (1987) Veterinary genetics. Oxford University Press, London

Ortiz de Zárate V, Bertignac M (2002) Analysis of tagging data from north Atlantic albacore (Thunnus alalunga): attrition rate estimates. Collect Vol Sci Pap Int Com Conserv AH Tuna 54:1438-1453

Pawson MG, Jennings S (1996) A critique of methods for stock identification in marine capture fisheries. Fish Res 25: 203-217

Penney AJ, Yeh SY, Kuo CL, Leslie RW (1998) Relationships between albacore (Thunnus alalunga) stocks in the southern Atlantic and Indian Oceans. In: Beckett JS (ed) Int Com Conserv AH Tuna Tuna Symp, Ponta Delgada, Azores, 10-18 June, 1996, p 261-271

Press W, Teukolsky SA, Vetterling W, Flannery BP (1992) Numerical recipes in FORTRAN: the art of scientific computing. Cambridge Univiversity Press, Cambridge

Pujolar JM, Roldán MI, Pla C (2003) Genetic analysis of tuna populations, Thunnus thynnus thynnus and T. alalunga. Mar Biol 143:613-621

Schwarz CJ, Schweigert JF, Arnason AN (1993) Estimating migration rates using tag-recovery data. Biometrics 49: 177-193

Sibert J, Holland K, Itano D (2000) Exchange rates of yellowfin and bigeye tunas and fishery interaction between Cross seamount and near-shore FADs in Hawaii. Aquat Living Resour 13:225-232

Slifkin M, Doyle RJ (1990) Lectins and their application to clinical microbiology. Clin Microb Rev 3:197-218

Sokal RR, Rohlf FJ (1995) Biometry. Freeman, San Francisco SPC (2002) Report of the 15th meeting of the Standing Committee on Tuna and Billfish (Honoluly, Hawaii, 22-27 July 2002). Available at: http://www.spc.org.nc/OceanFish/ Html/SCTB/SCTB15/ExecSum.pdf

Stequert B, Marsac F (1989) Tropical tuna - surface fisheries in the Indian Ocean. FAO Fish Tech Pap No. 282. FAO, Rome

Takagi M, Okamura T, Chow S, Taniguchi N (2001) Preliminary study of albacore (Thunnus alalunga) stock identification inferred from microsatellite DNA analysis. Fish Bull 99:697-701

Viñas J, Santiago J, Pla C (1999) Genetic characterisation and Atlantic Mediterranean stock structure of albacore, Thunnus alalunga. Collect Vol Sci Pap Int Com Conserv AH Tuna 49:188-190

Waldman JR (1999) The importance of comparative studies in stock analysis. Fish Res 43:237-246

Xiao Y (1996) A framework for evaluating experimental designs for estimating rates of fish movement from tag recoveries. Can J Fish Aquat Sci 53:1272-1280

Yeh SY, Hui CF, Treng TD, Kuo CL (1996) Indian Ocean albacore stock structure studies by morphometric and DNA sequence methods. In: Anganuzzi AA, Stobberup KA, Webb NJ (eds) Proceedings of the 6th Expert Consultation on Indian Ocean Tunas. Colombo, Sri Lanka, 2529 September 1995. IPTP, Colombo-Sri Lanka, p 258-263

Yeh SY, Treng TD, Hui CT, Penney AJ (1998) Mitochondrial DNA sequence analysis on albacore, Thunnus alalunga, meat samples collected from the waters off western South Africa and the eastern Indian Ocean. In: Beckett JS (ed) ICCAT Tuna Symp, Ponta Delgada, Azores, p 272

Yim M, Ono T, Irimura T (2001) Mutated plant lectin library useful to identify different cells. Proc Natl Acad Sci USA 98:2222-2225

Submitted: July 25, 2003; Accepted: August 3, 2004

Proofs received from author(s): October 13, 2004 